J. Clin. Chem. Clin. Biochem.

Vol. 18,1980 , pp. 585-590

\title{
Adsorption of Parathyrin: \\ Pitfall for Solid Phase Assays Using Radiolabelled Antibodies?
}

\author{
By H. Jüppner, H. Mohr and R.-D. Hesch ${ }^{1}$ )
}

Abteilung für Klinische Endokrinologie, Dept. Innere Medizin, Medizinische Hochschule Hannover

(Received December 20, 1979/March 26, 1980)

Summary: The physicochemical behaviour of parathyrin on surfaces was investigated. Parathyrin is bound to the wall of polyethylene, polypropylene and flint glass tubes. This adsorptive binding of the hormone, detected by labelled antibodies, is a time-dependent process which is complete within one hour.

The addition of plasma decreases but does not prevent adsorption. Coating of the tubes with an anti-N-regional or anti-C-regional antiserum decreases the sensitivity of the detection of 1-34,53-84 and 1-84 intact parathyrin, when performed in buffer. In the presence of plasma the increase of radiolabelled antibody detecting the parathyrin. was more pronounced when tubes were precoated with an anti-parathyrin antibody. The sensitivity of the 1-84 parathyrin assay was also reduced when incubation was carried out in the presence of high concentrations of parathyrinfragments, calcitonin, somatostatin or bovine serum albumin. Assay specificity seems to be related to the specificity of the labelled antibody for the respective hormonal fragment, not to that of the antibody used for coating the tubes. This investigation illustrates the necessity for the careful control of parathyrin assay conditions, e. g. non-specific binding of native parathyrin and radiolabelled tracers to laboratory reaction vessels.

\section{Adsorption von Parathyrin: \\ Werden dadurch Solid-Phase-Assays in Frage gestellt?}

Zusammenfassung: Untersucht wurde das physikochemische Verhalten von Parathyrin an verschiedenen Oberflächenstrukturen. Parathyrin bindet sich an Polyethylen, Polypropylen und Flintglas. Diese Adsorption des Hormons wurde gemessen unter Verwendung von ${ }^{125}$ I markierten Antikörpern. Der zeitabhängige Bindungsprozeß ist innerhalb einer Stunde abgeschlossen. Zusatz von Plasma vermindert die Adsorption, kann diesen Effekt jedoch nicht völlig verhindern. Die Assaysensitivität für 1-34-, 53-84- und intaktes Parathyrin wird reduziert, wenn die verwendeten Inkubationsgefäße zuvor mit anti-N- oder anti-C-regionalen Antiseren beschichtet werden und der Assay in Puffer durchgeführt wird. Bei Zusatz von Plasma bewirkt die vorherige Antikörperbeschichtung der Reaktionsgefäße schon bei niedrigen Hormonkonzentrationen einen steilen Anstieg des pararhyringebundenen ${ }^{125}$ I markierten Antikörpers. Reduziert wird die Sensitivität des 1-84-Parathyrin-Assays auch durch hohe Konzentrationen von Parathyrinfragmenten, Calcitonin, Somatostatin und Rinderserumalbumin. Die Spezifität der Nachweismethode wird anscheinend determiniert von der Spezifität des verwendeten radioaktivmarkierten Antikörpers für das zu messende Hormonfragment; nicht von dem Antikörper, 'der zur Beschichtung der Inkubationsgefäße verwendet wird. Die Untersuchungen veranschaulichen die Notwendigkeit der besonderen Uberwachung von Parathyrinnachweismethoden; insbesondere sollte die unspezifische Bindung von markiertem und nativem Hormon an Reaktionsgefäße kontrolliert werden.

\section{Introduction}

The adsorption of antibodies to polymeric surfaces was first utilized for solid-phase radioimmunoassay by Catt, Niall \& Tregear (1) and Catt \& Tregear (2) in 1967 to determine human growth hormone and human placental lactogen. In this system labelled and native antigen reacted directly with the solid phase antibody adsorbed to the plastic tubes.
In 1971 another principle for the determination of hormone concentrations was introduced by Addison et al. (3).

In this modification of immuno-assays, a first antibody was adsorbed to the surface of plastic tubes as described 1) Supported by the Deutsche Forschungsgemeinschaft (DFG):
He 593/10. 
$(1,2)$. In a second reaction the respective hormone was extracted onto the solid phase antibody. Bound hormone was then detected in a third incubation by a labelled second antibody. Thus, the amount of radioactivity measured depended on the concentration of cold hormone which was extracted during the second reaction. Binding of the hormone was a function of the amount of the first antibody coated to the tube. The kinetics of the complex reactions have been examined in more detail by Rodbard \& Feldman (4). This "two-site sandwich" method proved to be suitable for detecting insulin, human growth hormone, follicle stimulating hormone and parathyrin $(5,6,7)$. Our results presented here suggest that, in contrast to other observations, parathyrin-binding is not regulary related to the amount of antibody coated onto the tubes. This was not surprising since Hamilton et al.

(8) as well as Barrett et al. (9) were able to demonstrate that parathyrin is strongly adsorbed to solid phases, e.g. glass ware, polyethylene, polypropylene and polystyrene. When utilizing this effect we were able to set up a solid phase assay for intact parathyrin and some of its fragments without prior coupling of a first anti-N-regional antibody to the surface. The sensitivity of such a system is not diminished compared to the "two-site sandwich" assay; at high hormone concentrations (1000 pmol/1), the sensitivity of the assay is distinctly increased. Although our data are unusual at a first glance, carefully evaluation of the system made it suitable for measuring 1-84 and 1-34 parathyrin in the physiological range, when performed in buffer, and 53-84 and 44-68 only in higher molar concentrations. Certainly this phenomenon invalidates some traditional radioimmunochemical determinations of parathyrin.

\section{Materials and Methods}

1-84 bovine parathyrin was from Hormon-Chemie, München, GFR and revealed a purity of $10 \%$ compared to MRC standard $71 / 324$ (NBSB, London). Synthetic 1-34 human parathyrin (Brewer sequence) was from Dr. Rittel, Ciba-Geigy, Basel. All standards were stored in stock solutions containing $0.1 \mu \mathrm{g} / 50 \mu \mathrm{l}$ of parathyrin at $-60^{\circ} \mathrm{C}$ and diluted in assay-buffer just before assay. All results refer to dose response curves performed using standard dissolved in buffer but not in plasma if not stated otherwise. 28-48 bovine parathyrin, 44-68 human parathyrin, 53-84 bovine parathyrin and 53-84 human parathyrin were kindly provided by J. Zanelli, NBSB, London, and Dr. H. Keutmann, Boston, Mass., USA. Antibody A VIII-3, primarily reacting with the $C$-regional sequence of intact bovine parathyrin and human parathyrin as well, was from Dr. Bouillon, Rega Institut, Leuven, Belgium (10). Antiserum goat 1711 (bleed 5/15/74) against 1-34 human parathyrin was a generous gift from Dr. C. Arnaud, Mayo Clinic, Rochester, USA. AS 262 containing anti-N-regional and anti-C-regional bovine parathyrin populations was from Wellcome, Beckenham, England. Antiserum goat 108; also being anti-N- and Anti-C-regional, was kindly provided by Dr. Woodhead, Welsh National School of Medicine, Cardiff, Wales. This antiserum was raised against trichloroacetic acid extracts of human parathyroid adenomata. Antisera were labelled with ${ }^{125}$ I as described $(11,12)$. For the antibody goat 1711 an immunoadsorbent containing 1-34 human parathyrin of the Brewer sequence was used to extract antiserum for radioiodination. Incubation was carried out in polyethylene (Sarstedt 46/6), polypropylene (Sarstedt 46/6 P) or flint glass tubes (Minnerstädter Glaswaren- fabrik). Somatostatin (cyclic form) was from Serono, Freiburg, GFR. Salmon calcitonin from Armour Pharmaceutical Company Ltd., Eastbourne, England. Inúlin was from Merck, Darmstadt, GFR. Bovine and human serum albumin was from BehringWerke, Marburg/Lahn, GFR. All other reagents were of the highest purity available.

\section{Detection of 1.84 bovine parathyrin}

Tubes were incubated with $200 \mu \mathrm{l}$ of preextracted anti-N-regional populations of the anti-bovine parathyrin-antiserum AS 262. For this purpose whole antiserum was extracted onto 1-34 bovine parathyrin and eluted as described to yield anti-N-regional populations (13).

Control tubes remained untreated. After $18-24 \mathrm{~h}$ at room temperature the coated tubes were washed three times with a washing solution $(0.15 \mathrm{~mol} / 1 \mathrm{NaCl}, 0.1 \mathrm{~g} / 1$ Merthiolate, $5 \mathrm{~g} / 1$ bovine serum albumin). Incubation with 1-84 bovine parathyrin was carried out simultaneously with control tubes in a final volume of $200 \mu \mathrm{l}$. Hormone concentrations ranged from 8.5 to $2630 \mathrm{pmol} / 1$ diluted in NIRG-buffer (NIRG-buffer: $50 \mathrm{mmol} / \mathrm{l}$ sodium barbitone, $5.0 \mathrm{~g} / 1 \mathrm{NaCl}, 0.5 \mathrm{~g} / 1 \mathrm{NaN}_{3}, 20 \mathrm{mg} / \mathrm{l} \mathrm{non-}$ immune-bovine-globulin, $5.0 \mathrm{~g} / 1$ human serum albumin, $\mathrm{pH} 8.0$ ). Substances tested for their influence on the 1-84 binding were dissolved in NIRG-buffer and added in $100 \mu$ l. Control tubes received $100 \mu \mathrm{l}$ of the same buffer. After another $18-24 \mathrm{~h}$ at $4{ }^{\circ} \mathrm{C}$ all tubes were washed twice with $300 \mu \mathrm{l}$ NIRG-buffer and reacted with $200 \mu \mathrm{l}$ labelled antibody Bouillon A VIII-3 (5000 counts/min per tube) at $4^{\circ} \mathrm{C}$ for $24 \mathrm{~h}$. Tubes were then washed twice with $300 \mu$ l NIRG-buffer and counted for radioactivity. For time course experiments incubation periods and temperature were as indicated.

\section{Detection of 1-34 human parathyrin}

Tubes were coated with anti-N-regional populations of the antiserum goat 108 extracted onto 1-34 human parathyrin-immunoadsorbent (Brewer sequence) and eluted as described (13). 1-34 human parathyrin was added in concentrations ranging from 95-11900 pmol/1. After incubation and washing, labelled antibody goat 1711 was added. All other conditions were as described for 1-84 bovine parathyrin.

\section{Detection of 53-84 bovine parathyrin}

Tubes were coated with S 478 VI (14), a primarily anti-Cregional antiserum, diluted 1:1000. Concentrations of 53-84 bovine parathyrin were in the range $0.21-135 \mathrm{nmol} / 1$. After incubation and washing, labelled antibody Bouillon A VIII-3 was added. All other assay conditions were as described for 1-84 bovine parathyrin.

\section{Experiment for extraction specificity}

Untreated tubes were incubated either with intact bovine parathyrin $(0.039-5.0 \mu \mathrm{g} / \mathrm{l})$ or hormone fragments $(50.0-1000 \mu \mathrm{g} / \mathrm{l})$ dissolved in NIRG-buffer. All other conditions were as described for 1-84 bovine parathyrin.

\section{Results}

Parathyrin binding to different materials was investigated using reaction vials of polyethylene, polypropylene and flint glass. Bound parathyrin was detected by radiolabelled antisera. In figure 1 the binding of 15.5$500 \mathrm{pmol} / \mathrm{l}$ parathyrin is shown. Only minimal differences of bound radioactivity were observed between both plastic materials, while the flint glass assay exhibited a reduced extraction of parathyrin. In subsequent experiments only polyethylene tubes were used.

The time course of 1.84 bovine parathyrin binding to polyethylene tubes at $4{ }^{\circ} \mathrm{C}$ demonstrates a rapid saturation of the tubes, which is practicly complete for varying 


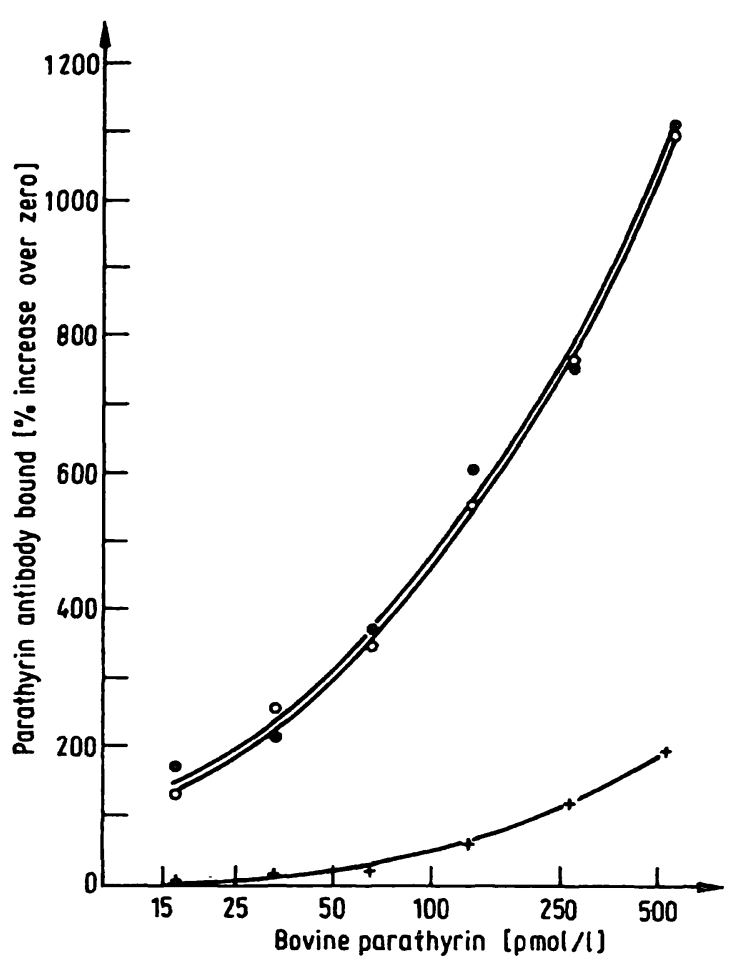

Fig. 1. Increasing concentrations of bovine parathyrin (16.5$525.0 \mathrm{pmol} / \mathrm{l}$ ) were incubated in polyethylene $\bullet-\bullet$, polypropylene $0-0$ and flint glass +-+ tubes for 18-24 h at $4{ }^{\circ} \mathrm{C}$. Parathyrin bound to the different tubes was detected by the labelled antibody.

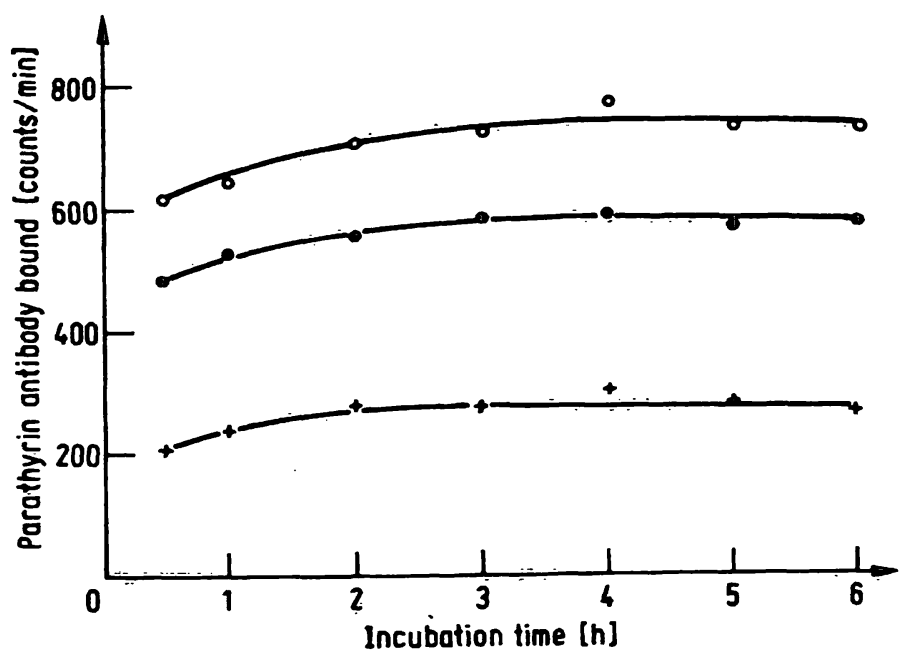

Fig. 2. Three concentrations of bovine parathyrin $(50,250$ and $500 \mathrm{pmol} / \mathrm{l}$ ) were incubated in polyethylene tubes at $4{ }^{\circ} \mathrm{C}$ for increasing periods $(30 \mathrm{~min}-6 \mathrm{~h}$ ). Parathyrin bound after the respective time was detected by labelled antibody. — $500 \mathrm{pmol} / 1 \multimap .250 \mathrm{pmol} / \mathrm{l}+\ldots 50 \mathrm{pmol} / \mathrm{l}$.

concentrations of hormone within 2-3 h (fig. 2). The same result was observed when incubation was carried out at room temperature (datà not shown). To further elucidate these findings, increasing amounts of $1=84$ bovine parathyrin were incubated for $1-6 \mathrm{~h}$ at $4^{\circ} \mathrm{C}$ (fig. 3). This showed identical dose-response-curves over the whole range of hormone concentration. To describe the kinetics of the fixation of the radiolabelled

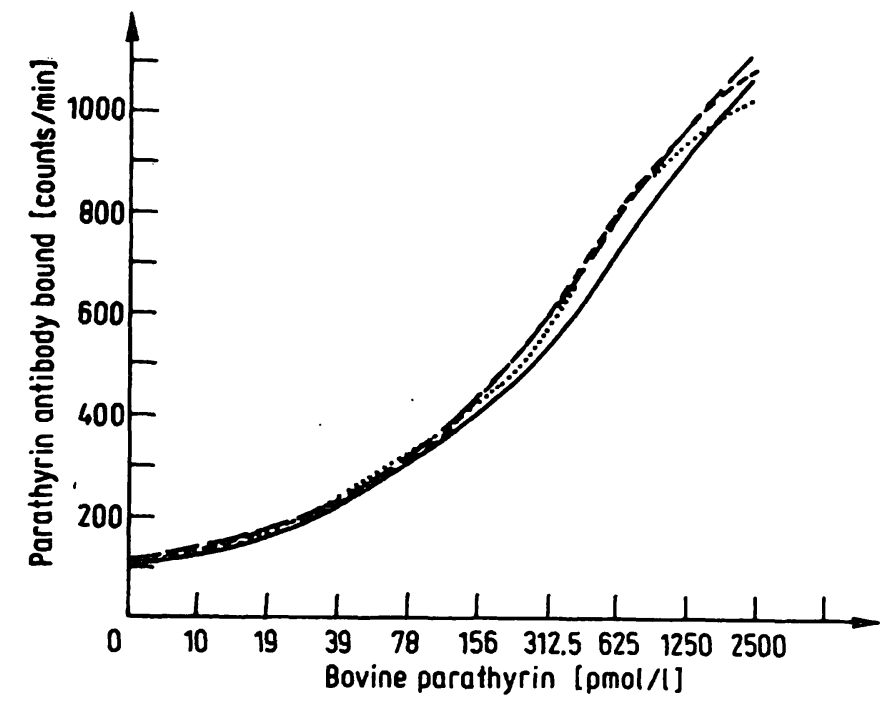

Fig. 3. To illustrate that bovine parathyrin is bound very rapidly to polyethylene, the tubes were incubated with increasing concentrations of parathyrin $(5.0-2500.0 \mathrm{pmol} / \mathrm{l})$ for $1-6 \mathrm{~h}$ at $4^{\circ} \mathrm{C}$. Bound hormone was determined by labelled antibody.

$-1 \mathrm{~h} \cdots \cdot 2 \mathrm{~h} \quad--4 \mathrm{~h} \quad \cdots \cdot 6 \mathrm{~h}$

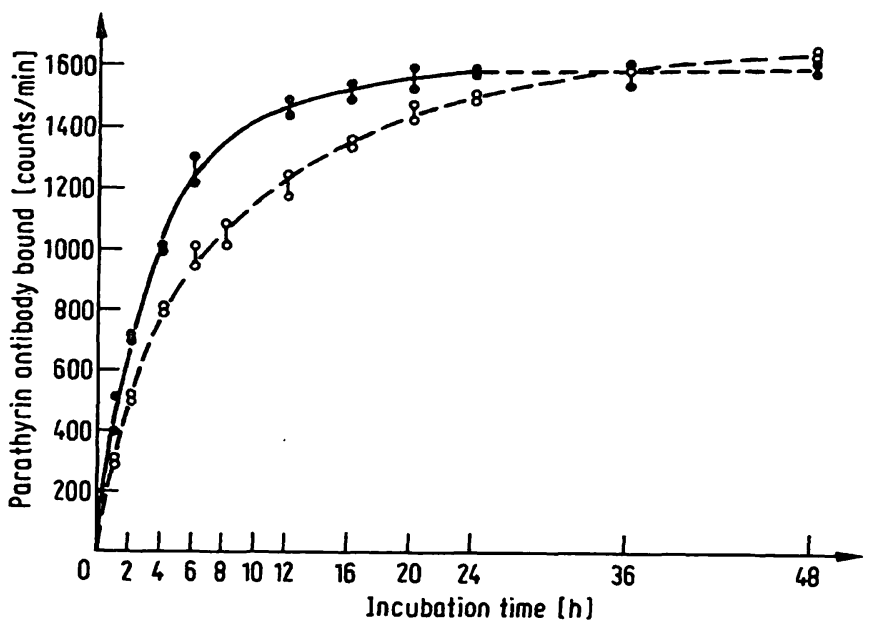

Fig. 4. Bovine parathyrin ( $5000 \mathrm{pmol} / 1)$ was incubated in polyethylene tubes for $18-24 \mathrm{~h}$ at $4{ }^{\circ} \mathrm{C}$. Parathyrin bound to tubes was then detected by labelled antibody. This second reaction was carried out for $2-48 \mathrm{~h}$ at room temperature $-\longrightarrow$ and $4^{\circ} \mathrm{Co}$ - -0 .

antibody we followed its binding onto bovine parathyrincoated tubes over a time period ranging from $2-48 \mathrm{~h}$ (fig. 4). It was found that this reaction finishes at room temperature after about $24 \mathrm{~h}$, whereas at $4{ }^{\circ} \mathrm{C}$ about $36 \mathrm{~h}$ are required. Half maximal binding is reached at $3 \mathrm{~h}$ and $4 \mathrm{~h}$ respectively.

We next investigated the behaviour of bovine parathyrin extraction onto uncoated and antibody precoated tubes detected by radiolabelled antiserum as described (13). $1.84,1-34$ and 53-84 extraction onto the tubes was followed. A remarkable difference was found in the dose-response-curves between untreated and antibodycoated tubes. $1-84$ bovine parathyrin extraction (fig. 5) 


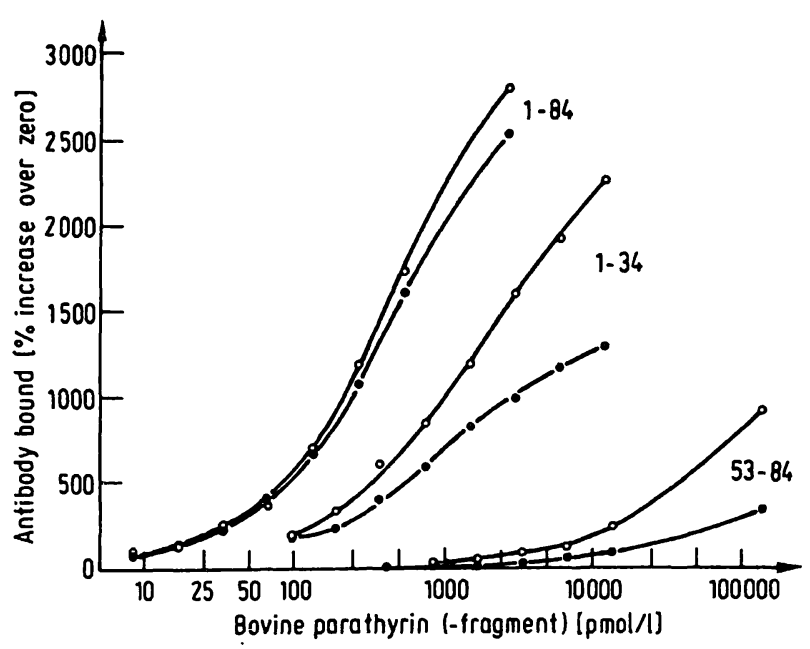

Fig. 5. In a first reaction 1-84-(8.5-2630 pmol/1), 1-34-(95.0$11900 \mathrm{pmol} / \mathrm{l})$ or $53-84-(0.21-135.0 \mathrm{nmol} / \mathrm{l})$ parathyrin was incubated in polyethylene tubes, untreated $0-0$ or precoated with a first antibody $\bullet \longrightarrow$, for $18-24 \mathrm{~h}$ at $4{ }^{\circ} \mathrm{C}$. In a second reaction the respective hormone was detected by a labelled second antibody.

was less effective at higher hormone concentrations when antibody coated tubed were used. For the 1-34 and the 53-84 parathyrin fragments, the loss of extraction efficiency by using antibody-coated tubes was even more pronounced. In the 1-34 study the increase of radioactivity was reduced to $96.5 \%$ at $0.95 \mathrm{nmol} / 1$ and to $56.7 \%$ at $11.9 \mathrm{nmol} / \mathrm{l}$. In the $53-84$ study these figures are $57.3 \%$ at $2.1 \mathrm{nmol} / \mathrm{l}$ and $36.3 \%$ at $135.0 \mathrm{nmol} / \mathrm{l}$, respectively. For the $1-84$ human parathyrin the reduction is only $10 \%$ at $2.65 \mathrm{nmol} / \mathrm{l}$, whereas at lower concentrations no significant difference between both methods of tube preparation was observed. Most interesting, however, is that coupling of a first antibody to the tube does not increase the sensitivity or specificity of the detection method for the different parathyrin-peptides. In a final series of experiments, the adsorption of 1.84 bovine parathyrin to antibody coated and noncoated tubes was followed, either in the presence or absence of plasma, to elucidate potential protective effects of plasma proteins on parathyrin adsorption. If the incubation was carried out in the presence of plasma $(1+1-$ NIRG-buffer + plasma $)$, the adsorption efficiency was reduced compared to the buffer incubation (fig. 6). In this case prior coating with an anti-N-regional antibody (extracted and eluted as described) increased the adsorption of parathyrin onto the wall, compared to untreated tubes. The adsorption rate difference was $96.5 \%$ higher at $31.25 \mathrm{pmol} / 1$ and $93.2 \%$ at $250 \mathrm{pmol} / \mathrm{l}$, i.e. a parathyrin value of $25 \mathrm{pmol} / 1$ determineed in a precoated tube would react as $62.5 \mathrm{pmol} / 1$ in a tube where parathyrin was adsorbed onto the tube without antibody precoating. However, the addition of plasma certainly did not prevent the adsorptive binding of 1-84 bovine parathyrin; yet it is added for this purpose in the determination of parathyrin in many assay systems. Because of the inhibitory effect of plasma, the influence of different peptides on the binding of 1-84 bovine para-

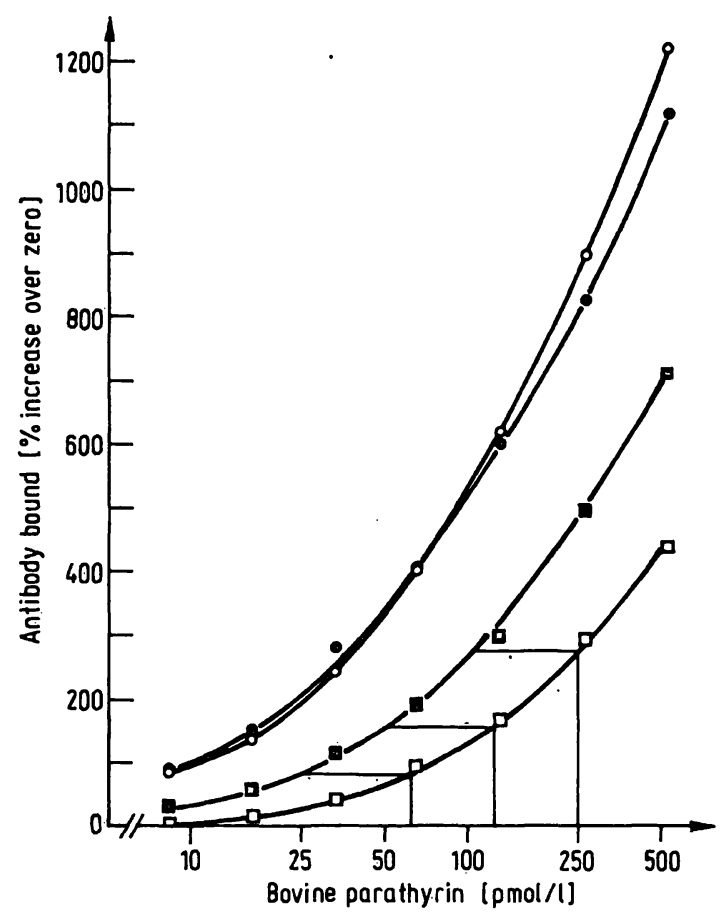

Fig. 6. 1-84-bovine parathyrin was incubated for $18-24 \mathrm{~h}$ at $4{ }^{\circ} \mathrm{C}$ either in antibody-coated or untreated polyethylene tubes in the presence or absence of plasma. Bound parathyrin was then detected by the labelled second antibody. - 0 without coating buffer system - - with coating $\square-\square$ without coating -_ with coating plasma system

thyrin was tested. As shown in table 1 high concentrations of parathyrin-fragments, calcitonin and somatostatin, reduced the adsorption of native bovine parathyrin onto polyethylene tubes in a dose dependent manner. Bovine serum albumin at concentrations of $50 \mathrm{~g} / 1$ resulted in a reduction of parathyrin adsorption, which was comparable to that of plasma. Simultaneous incubation with inulin $(1.0 \mathrm{~g} / \mathrm{l}$ ) or gelatin (up to $2 \mathrm{~g} / \mathrm{l}$ ) had no effect on the binding of parathyrin onto uncoated surfaces. Adsorption without prior antibody coating of the tubes was observed for bovine and human parathyrin, and was not avoided even in the presence of $8 \mathrm{~mol} / \mathrm{l}$ urea. The fixation was not decreased when parathyrin was oxidized with $\mathrm{H}_{2} \mathrm{O}_{2}$ (data not shown). Figure 7 illustrates the specificity of the labelled antibody used for the experiments. Only intact hormone is determined in physiological concentrations, whereas fragments are detected only in high, supraphysiological ranges. The 28.48 and the 1.34 (up to $1 \mathrm{mg} / \mathrm{l}$ ) peptides did not react at all with the $C$-regional radiolabelled antibody (data not included in fig. 7)..Finally it should be mentioned that coating of the tubes with appropriate non-immune-gamma-globulin did not influence the parathyrin extraction, or the fixation of the radiolabelled antibody gamma globulin. Repeated washing of the tubes onto which parathyrin had been adsorbed at $4{ }^{\circ} \mathrm{C}$ did not influence the amount of parathyrin detected by the radiolabelled antibody in the second incubation, thus indicating firm physiological binding. 
Tab. 1. In the first reaction, intact bovine parathyrin $(5 \mu \mathrm{g} / 1)$ is incubated in polyethylone tubes for $18-24 \mathrm{~h}$ at $4^{\circ} \mathrm{C}$ in the presence of different peptides and bovine serum albumin (concentrations as indicated). During the second reaction intact bovine parathyrin bound to the tubes is detected by the labelled antibody.

\begin{tabular}{|c|c|c|c|c|}
\hline . & & & $\begin{array}{l}\% \text { increase } \\
\text { over zero }\end{array}$ & $\begin{array}{l}\% \\
\text { inhibition } \\
\text { compared } \\
\text { to the } \\
\text { increase } \\
\text { of } 5 \mu \mathrm{\mu g} / 1 \\
1-84 \\
\text { bovine } \\
\text { parathyrin }\end{array}$ \\
\hline $\begin{array}{l}\text { standard } \\
\text { curve }\end{array}$ & $\begin{array}{l}0.156 \\
0.3125 \\
0.625 \\
1.25 \\
2.5 \\
5.0\end{array}$ & $\begin{array}{l}\mu g / 1 \\
1-84 \\
\text { bovine } \\
\text { parathyrin }\end{array}$ & $\begin{array}{r}187.9 \\
351.7 \\
607.4 \\
958.6 \\
1452.3 \\
2161.5\end{array}$ & \\
\hline \multirow{5}{*}{$\begin{array}{l}5.0 \mu g / 1 \\
1-84 \\
\text { bovine } \\
\text { parathyrin }\end{array}$} & $\begin{array}{r}2.5 \\
5.0 \\
25.0\end{array}$ & $\begin{array}{l}\mathrm{mg} / \mathrm{l} \\
1-34 \text { human } \\
\text { parathyrin }\end{array}$ & $\begin{array}{l}1843.1 \\
1542.9 \\
1291.1\end{array}$ & $\begin{array}{l}14.7 \\
28.6 \\
40.3\end{array}$ \\
\hline & $\begin{array}{r}250.0 \\
500.0 \\
2500.0\end{array}$ & $\begin{array}{l}\mu \mathrm{g} / 1 \\
53-84 \text { bovine } \\
\text { parathyrin }\end{array}$ & $\begin{array}{l}2087.9 \\
1965.4 \\
1564.7\end{array}$ & $\begin{array}{r}3.6 \\
9.1 \\
27.6\end{array}$ \\
\hline & $\begin{array}{r}5.0 \\
25.0 \\
50.0\end{array}$ & $\begin{array}{l}\mathrm{mg} / \mathrm{l} \\
\text { calcitonin }\end{array}$ & $\begin{array}{r}1334.0 \\
982.3 \\
788.1\end{array}$ & $\begin{array}{l}38.3 \\
54.6 \\
63.5\end{array}$ \\
\hline & $\begin{array}{r}5.0 \\
25.0 \\
50.0\end{array}$ & $\begin{array}{l}\mathrm{mg} / \mathrm{l} \\
\text { somatostatin }\end{array}$ & $\begin{array}{l}1663.0 \\
1326.3 \\
1101.7\end{array}$ & $\begin{array}{l}23.0 \\
38.6 \\
49.0\end{array}$ \\
\hline & $\begin{array}{r}5.0 \\
25.0 \\
50.0 \\
500.0 \\
2500.0 \\
5000.0 \\
50000.0\end{array}$ & $\begin{array}{l}\text { mg/l } \\
\text { bovine } \\
\text { serum } \\
\text { albumin }\end{array}$ & $\begin{array}{l}2253.3 \\
2222.1 \\
2268.9 \\
2242.9 \\
2088.7 \\
2073.3 \\
1500.1\end{array}$ & $\begin{array}{l}- \\
\overline{-} \\
- \\
3.4 \\
4.1 \\
30.6\end{array}$ \\
\hline
\end{tabular}

\section{Discussion}

The binding of peptides, globulins and amino acids onto different surfaces is a well known phenomenon and was the subject of a number of previous studies $(1,2,8,15)$. Especially parathyrin has been known for a long time to impose considerable problems with respect to adsorption onto surfaces $(8,9)$. The data presented in this communication demonstrate that parathyrin is effectively fixed to a variety of materials even in the presence of $5 \mathrm{~g} / 1$ human serum albumin. Especially plastic tubes seem to have a high ability to bind parathyrin. Adsorption of parathyrin onto untreated tube walls is a very rapid process.

Maximal parathyrin fixation within one hour, over a wide concentration range, was temperature-independent. The labelled antibody reached its binding plateau during the second incubation after about $24 \mathrm{~h}$, and this reaction was found to be temperature-dependent, illustrating that parathyrin binding to the tube is distinctly different from

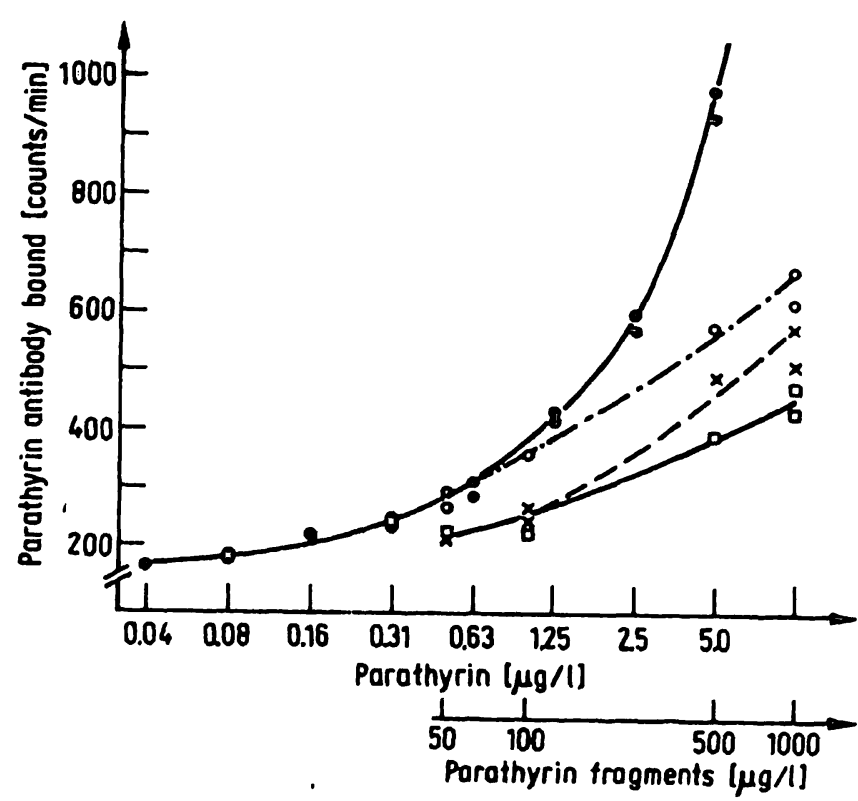

Fig. 7. In a first reaction 1-84-, 44-68-, 53-84-parathyrin was incubated in polyethylene tubes for $18-24 \mathrm{~h}$ at $4^{\circ} \mathrm{C}$. In a second reaction the respective fragments were detected by a labelled second antibody mainly reacting with the C-region of the intact hormone.

- 1-84-bovine parathyrin $0 \cdot-\cdot-0$ 53-84-human parathyrin $x--x$ 53-84-bovine parathyrin $\square$ 44-68-human parathyrin

antibody binding to the hormone. The strong adsorption of the hormone may be related to the great number of hydrophobic amino acids in the parathyrin molecule which will induce its binding to a chemically appropriate matrix by hydrophobic forces. This is also observed for intact parathyrin and several fragments, although the latter are less efficiently extracted on a molar basis. The type of binding is, of course, not specific for the parathyrin structure and that of its fragments. The hormone can be displaced from adsorptive binding to the tube by a variety of other peptides, although only when present in large excess (tab. 1). Similar results were obtained if the study was performed in plasma. In this case, satisfactory results were achieved only for the extraction of 1-84, compared to the 1-34 and 53-84 fragments. Using antibody-precoated tubes the efficiency of adsorption is only increased when plasma is present, in contrast to the behaviour in buffer. Surprisingly the "nonspecific adsorptive binding" is not totally prevented, although such an assumption is implicitly made for most radio immunoassay systems for the detection of parathyrin. A similar observation has already been described by Hesch et al. (13), where a standard curve for plasma assay in tubes precoated with specifically purified anti-N-regional antiserum was compared to a standard curve prepared in tubes precoated with native antiserum (dilution 1:1000). The apparent increase of sensitivity described was probably related to the prior affinity purification step of the antibody used for coating, while the lower demonstrated the "nonspecific adsorptive binding" similar to that shown in figure 6 . These results indicate that yet 
unknown plasma fractions interfere with the adsorption of parathyrin to the plastic surface. Surprisingly this inhibitory plasma effect was more pronounced for the 1-34 and 53-84 fragments and may indicate either the inhibition of adsorption, or an increased binding of fragments onto plasma protein fractions. Furthermore, plasma proteins may mask binding sites within the hormone which are specific for the labelled antibody.

From our observations it seems possible that adsorption occurs preferentially at the $\mathrm{NH}_{2}$-region (residues 1-34). This part of the sequence may penetrate more into the matrix and undergo noncovalent binding to the plastic material. The remaining part of the molecule, which is more compact (16), will then be detected by the labelled antibody. This offers a further explanation for the more intense binding of intact parathyrin, in contrast to the parathyrin fragments. The difference in adsorption between fragment 1-34 and 53-84 is evident. It can best be explained by different chemical groups undergoing binding to plastic surfaces. The 1-34 parathyrin fragment is a more hydrophobic, whereas the 53-84 fragment is a more hydrophilic peptide. Even if the binding sites of the antisera are not fully exposed to the peptides this would not account for the differences observed. Our results have several implications:

i. Intact parathyrin is adsorbed onto surfaces to a considerable extent. In contrast to another study published very recently on the same phenomenon, we have analyzed unlabelled parathyrin peptides, which certainly behave differently from ${ }^{125} \mathrm{I}$ labelled intact hormone in which the conformation is altered (16). Degradation of the parathyrin at the temperature used here has never been observed and therefore cannot invalidate our results.

ii. In assays for intact parathyrin, appropriate controls must be run to show that effective protection against adsorption is achieved. From our results one may expect that different plasma samples will have different effects on the loss of parathyrin from the reaction milieu. In a direct radioimmunoassay, the adsorption of fragments present, for example, in uremic sera in large excess, may considerably interfere with the reaction of intact hormone. It would be an advantage of the "two-sitecoated-tube assay" that its specificity is determined by the detection of the $\mathrm{COOH}$ end of the molecule in the reaction.

iii. Some criticism is attached to the assumptions of "two-site-coated-tube assays". In contrast to what is assumed from results of such assay systems for parathyrin $(7,13)$, coating of the tubes is not relevant for specificity, or for sensitivity when intact parathyrin is determined in buffer solution. Specificity of such assay seems to be related very much to the specificity of radiolabelled antiserum as shown in figure 7 . Sensitivity is reduced in an assay where intact parathyrin is determined in plasma samples, but this only may partly be improved by precoating the reaction tube with an anti-N-terminal antiserum. This effect is, however, poorly understood. Whatever the final explanation may be, the design of the "two-site-coated-tube assay", although theoretically universal in specificity and sensitivity, presents several technical problems. This must be taken into account when interpreting results from such assays.

A more reliable approach would be to couple specific first antisera to inert solid phases. However, the assay is very suitable and specific, when carried out in buffer, and includes the advantage that even high concentrations $(8 \mathrm{~mol} / \mathrm{l})$ of urea do not interfere. For this reason and the facility in handling this system, it may be very useful for several biochemical purposes (for example: during the purification of the hormone). Our findings demonstrate the necessity to further elucidate the adsorptive binding of native parathyrin or its fragments and radiolabelled parathyrin tracers used for radioimmunochemistry.

\section{References}

1. Catt, K. J., Niall, H. D. \& Tregear, G. W. (1967), Nature 213, $825-827$.

2. Catt, K. \& Tregear, G. M. (1967), Science 156, 1570-1571.

3. Addison, G. M. \& Hales, C. N. (1971), Horm. Metab. Res. 3, $59-60$.

4. Rodbard, D. \& Feldmann, Y. (1978), Immunochemistry 15 (2), 71-76

5.. Addison, G. M., Hales, C. N., Woodhead, J. S. \& O'Riordan, J. L. H. (1971), J. Endocrinol. 49, 521-530.

6. Woodhead, J. S., Davies, G. M., Hales, C. N. \& Lehmann, H. (1977), J. Endocrinol. 73, 279-288.

7. Readhead, C, Addison, G. M., Hales, C. N. \& Lehmann, H. (1978), J. Endocrinol. 59, 313-323.

8. Hamilton, J. W., Spierto, F. W., MacGregor, R. R. \& Cohn, D. V. (1971), J. Biol. Chem. 246, 3224-3233.

9. Barrett, P. Q. \& Neumann, W. F. (1978), Biochim. Biophys. Acta 541, 223-233.

10. Bouillon, R., Koninckx, Ph. \& DeMoor, P. (1974), title in: "Radioimmunoassay and Related Procedures in Medicine", IAEA, Vienna, Vol. 1, 353-365.

11. Woodhead, J. S., Addison, G. M. \& Hales, C. N. (1974), Br. Med. Bull. 39, 44-49.

12. Miles, L. E. M. \& Hales, C. N. (1968), Biochem. J. 108, 611-618.

13. Hesch, R. D., McIntosh, C. H. S. \& Woodhead, J. S. (1975), Horm. Metab. Res. 7, 347-351.

14. Hehrmann, R., Wilke, R., Nordmeyer, J. P. \& Hesch, R. D. (1976), Dtsch. Med. Wochenschr. 101, 1726-1729.

15. Mizutani, T., Mizutani, A. (1977), Anal. Biochem. 83, 216-221.

16. Fiskin, A. M., Cöhn, D. V. \& Peterson, G. S. (1977), J. Biol. Chem. 254, 8261 $=8268$.

Prof. Dir. R.-D. Hesch

Abt. für Klinische Endokrinologie Dept. Innere Medizin

Medizinische Hochschule Hannover

Karl-Wiechert-Allee 9

D-3000 Hannover 61

J. Clin. Chem. Clin. Biochem. / Vol. 18, 1980 / No. 9 